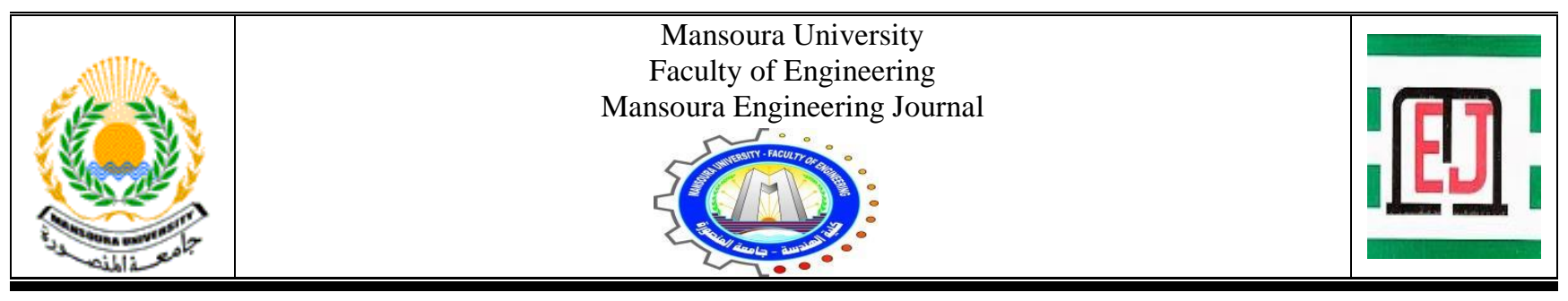

\title{
The Vertical Greenery Systems Significant Role in Achieving Better Architectural and Urban Thermal Performance
}

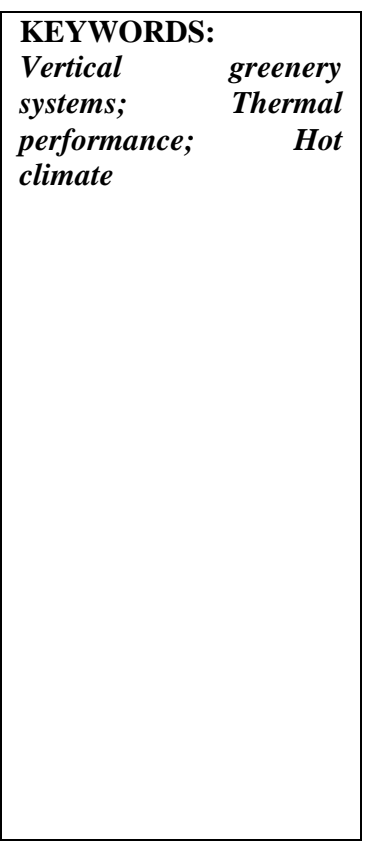

\author{
Ahmed A. Morsi* and Nesma A. Zakaria
}

\section{INTRODUCTION}

A s sustainable building design features, Vertical greenery systems have gained a significant role as

Received: (26 January, 2021) - Revised: (16 June, 2021) - Accepted: (22 June, 2021)

*Corresponding Author: Ahmed A. Morsi, Associate prof. of urban design and architecture Faculty of Fine Arts, Helwan University, Egypt (email: masterlinegroup@yahoo.com)

Nesma A. Zakaria, Assistant Professor at Architecture Department, Faculty of Fine Arts, Helwan University, Egypt (email: nesma.elian@hotmail.com) they can enhance a building's environmental impact. VGS indicate for growing vegetation on a vertical-profile and can be referred to as the terms including vertical greenery systems, vertical landscaping, vertical garden, and bio-walls [1].

Shading and evaporative cooling advantages offered by plants have steadily been lost due to the permanent expansion of artificial and enclosed surfaces that displace green spaces in urban areas.

Vegetation can present a significant performance in the urban climate and in buildings' climate zone. With buildings, the combination of the green coverage on roofs, facades, and open areas in the region of buildings may have certain vegetative climatic influences. 
The common usage of vertical gardens not just shows a gre at opportunity to reduce the effect of the Urban Heat Islad (U $\mathrm{HI}$ ) by shading and evapotranspiration due to the huge number of building facades but is also an extremely effective way to enhance the urban landscape [2].

Living walls (LWS) and Green Facades (GFS) are the two main classifications of vertical greenery systems. Vegetation, structures, and growing media are made up of them. Plants are essential and must be chosen by the system type used, ecological factors, budget, and expected level of maintenance. Growing media is where the plants' roots find their nutrients. It can be lightweight soil, normal soil, foam or felt. The natural soil composed of animals and plants decaying offer plant growth with nutrients. A stable soil, made from minerals, peat moss, and compost, is lightweight soil. Vegetation are planted into felt pockets, felt is a soil substrate that allows plant growth. and by water, nutrients are created. Foam is a light, durable substrate that provides the plants with nutrients from the water [3]. The growing media types identify the structure's type that can take a living wall or green façade form.

The growing media is established on the ground of VGS and the vegetation expand to cover the wall vertically. The growing media can be placed vertically on the wall surface. The first type is a green façade and the second type is a living wall. In traditional architecture, these systems were widely used, primarily because of their aesthetic influence, but also because of the effects of heat reduction [4].

The current research focuses on the effect of VGS on hotclimate environments, observing and tracing recent temperature studies, and assessing the thermal efficiency of these systems. Subsequently, the introduction of new approaches to enhance their performance. VGS terminology, definitions, categories, and benefits are presented for this reason.

\section{RESEARCH QUESTIONS}

- What is the most effective VGS category for reducing the building's temperature?

- Compared to a greenery façade, is there a variation among the air temperature next to a bare façade?

- Does the VGS change the urban heat island effect?

- Advantages and disadvantages of VGS classifications.

- Challenges and limitations facing the usage of VGS in Egypt and Mena region.

\section{METHODOLOGY}

Throughout the first section, the paper provides analytical evidence on the idea of vertical green walls, classifications, and systems. The second section analyses the applications of VGS and its influence on the thermal performance of both buildings and the urban context, the third part will present the most successful international \& Regional attempts of using the VGS, to set the Pro's and Con's of VGS.

The methodology would firstly observatory by highlighting the Functional \& Environmental Values of VGS, an analytical approach by reviewing some international, examples for the Functionality \& Sociability of Public Spaces. The research concludes with an approach to achieve better thermal performance using VGS.

TABLE 1

THE RESEARCH METHODOLOGY (SOURCE: RESEARCHER)

\begin{tabular}{c} 
Literature Review / Analytical Evidence \\
\hline Types of VGS \\
\hline Case studies Analysis / Parameters \\
\hline VGS Benefits \\
\hline Challenges and limitations of VGS usage in Egypt \& Mena region \\
\hline An Approach to Achieve Better Thermal Performance \\
Findings and discussion
\end{tabular}

\section{LITERATURE REVIEW}

In the first section, this paper provides a general literature review on terminology, definitions, categories, and benefits for vertical greenery systems (VGS). The research materials were created from various source forms, such as books, conference papers, and journal articles, Majority of them are records that are up-to-date and they are relevant to recent times.

It is possible to describe vertical greening systems (VGS) as structures that enable vegetation to expand along an interior wall or a façade of a building. Though they are still evolving, these systems are becoming popular and more information is required about their special influences.

In the application of all types of vertical greenery systems, authors use various terminologies, some use the word "Vertical Gardens" and others name them "Vertical Greening Systems," "Vertical Landscaping", "Vertical Greenery Systems," or "Green Vertical Systems," [5].

Francis R. \& Lorimar J. (2011) introduced another term called "Bio-walls," described as a green facade or living wall which is placed indoors, primarily to improve the indoor environment and the atmosphere. The VGS Theory applies to wholly systems that enable a vertical surface to be greened (e.g., walls, facades, partition walls, etc.) with a variety of plant species, with all the growing plants' solutions on a building's wall [2], [6].

\section{A. Classifications of VGS}

Vertical greenery systems are divided into two major categories: living walls (LWS) and Green façades (GWS), ranging from the simplest arrangement towards the most complicated and modern design. The categories are based on vegetation kind and construction system. Surface temperatures, air ambient, and also heat flux, can be reduced by any of these systems.

There is indeed an apparent difference among green façade (GFS), which climbing plants typically grow across the wall 
covering, and the latest ideas of living walls (LWS), that require technologies and materials to sustain a broader type of plants, producing a uniform surface growth [7].

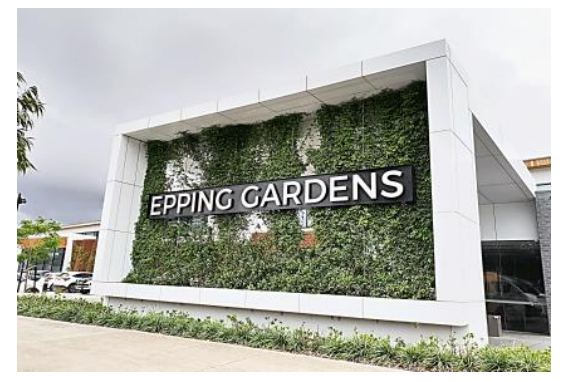

Figure 1, GFS, Epping Gardens, Australia. (source: https://fytogreen.com.au/epping-gardens-aged-care/)

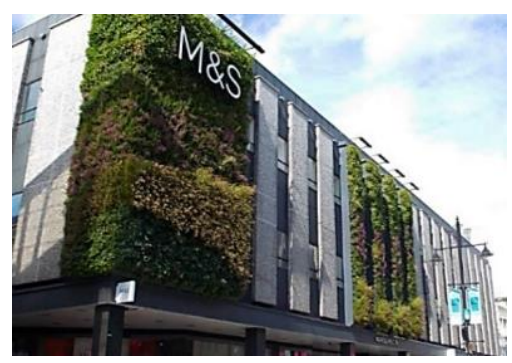

Figure 2, LWS, M \& S Newcastle, UK (source: https://livingwalls.ie/gallery/ms-newcastle/)

\section{1) Green Façade Systems (GFS)}

Green facades (GFS) depend on the implementation (evergreen or deciduous) of hanging or climbing plants across the wall. In case they are attached at a specific height, plants may grow up the vertical wall, like popular examples, or grow down the vertical wall. It is possible to categorize green facades as direct or indirect. The direct greenery in which vegetation is directly connected to the wall. While the indirect greenery comprises a vegetation supporting structure [7], (mainly on a trellis framework or on a wire). Directly within the soil or planter boxes, both of these options can be planted. [8], and have a life span of even more than fifty years. Climbing plants can expand around 3 meters to 10 meters during the first four years on a green façade. Compared to living walls, design, implementation, and the maintenance of GFS is much more precise in the forward direction.

Traditional greenery facades are known as a Direct greening system, which consist of self-clinging climbers, directly rooted in the ground (such as ivy that is capable of climbing structures without using expansion supports), Indirect greenery systems involve Modular and Continuous methods. Continuous guides are limited to a single system of support that directs to plant growth along the entire surface. Similar solutions are GFS with modular trellises, but they arise from the construction of many modules along the surface. The primary variations are modular trellises that include plant rooting vessels and a special support system for directing the vegetation development [7].

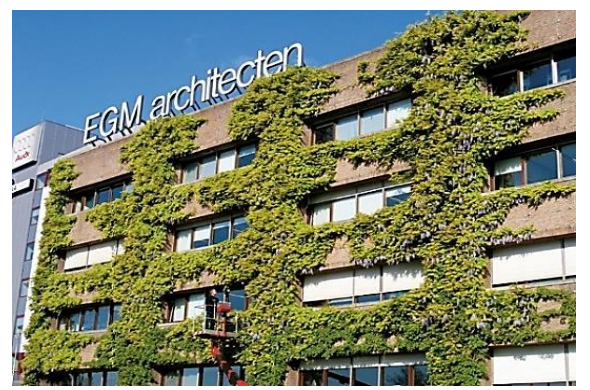

a. Direct Greenery System.

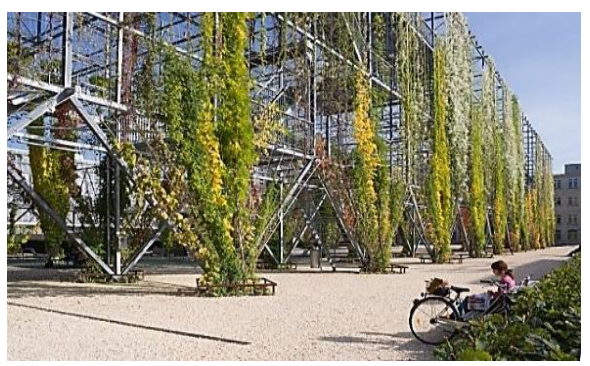

b. Indirect Greenery System.

Figure 3, The subcategorize of GFS (source: https://www.urbangreenbluegrids.com/measures/green-facades/)

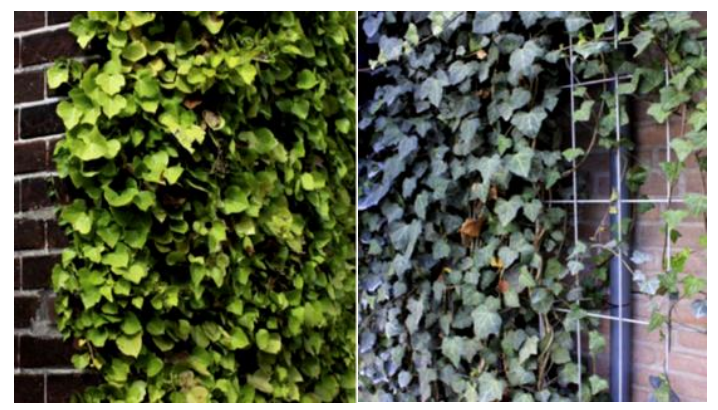

Figure 4, a. Direct facades (left), b. Indirect facades (right), (Source: [9])

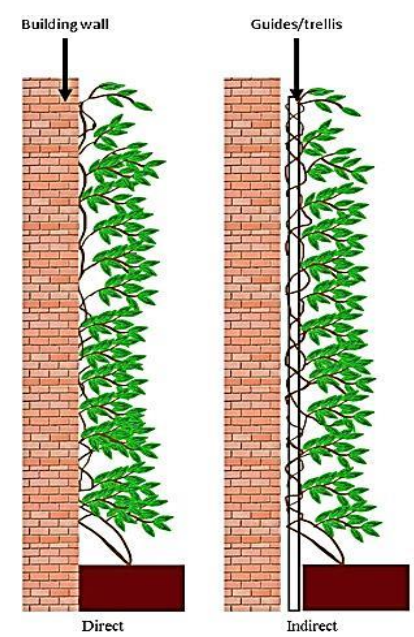

Figure 5, Schematic diagram of subcategorize of GFS, (Source: [10])

GFS efficiency depends directly on the form and weight of the leaves [6]. Among larger leaves, small leaves could grow, 
fill gaps, and produce thick foliage for shading. In addition, the air is able to flow via the leaves and ventilate all the systems. Green facades not only minimize heat in hot climates but it also reduces the air cavity temperature situated in between the GFS and the surface of the wall [11].

\section{2) Living Wall Systems (LWS)}

Living walls (LWS) are characterized, as walls that contain vegetation in their structure system and don't allow the plants to be rooted as a green façade in the substrate at the bottom of the wall [6]. In the field of wall cladding, LWS is a very recent area of innovation. They provide rapid coverage along the vertical surface of broad surfaces and more stable growth, reaching higher regions, and adapting to all buildings kinds. To encourage a range of diversity and density of plant species, LWS are made of extended polystyrene, plastic, steel frame, and synthetic fabric. They also make it possible to incorporate a larger range of plant types (grasses, shrubs, seasonal plants, succulents, etc.), selected to achieve aesthetic effects according to climate conditions, drought tolerance, and root growth [12].

Depending on the implementation method, LWS can be divided into two types: modular or continuous. Modular LWS are special-dimensional components that include growing media where plants are grown. Continuous LWS depends on the use of lightweight and permeable screens wherein plants are separately included. As Vertical Gardens, continuous living walls are known [7].

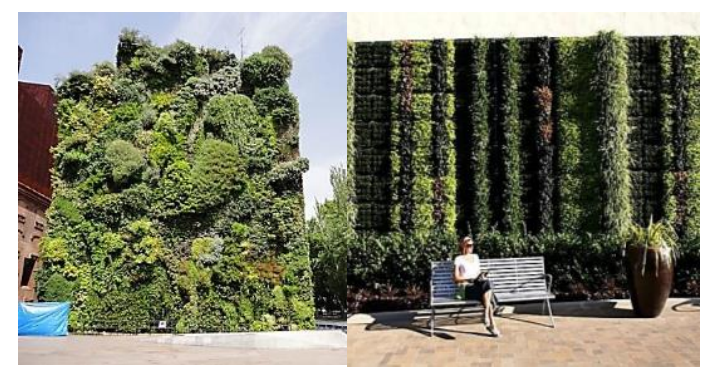

$$
\begin{aligned}
& \text { I. Continuous LWS Modular LWS } \\
& \text { Figure 6, Typologies of LWS. }
\end{aligned}
$$

(source: https://www.greenroofs.com/projects/fashionvalley-mall-living-wall/)

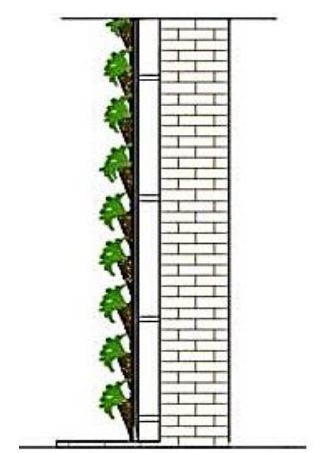

I. Continuous LWS. Figure 7, Schematic diagram of subcategories of LWS.
LWS indicates plants growing in planter boxes that could be extended to wall connected modular systems without relying on rooting areas at the ground level and generating mechanized irrigation. Modular LWs characterize prevegetated panels with various supporting elements in which plants grow, such as (planter tiles, trays, flexible bags, and felt pockets) As the field is constantly evolving, this system provides more possibilities for the designer. These subsystems are mostly focused on hydroponic techniques [7], [13]. The supply of water is usually provided by an irrigation system mounted at top of the structure, while the permeable layer ensures that nutrients and water are distributed uniformly, the construction of LWS is more complex than GFS and corresponds to all new buildings.

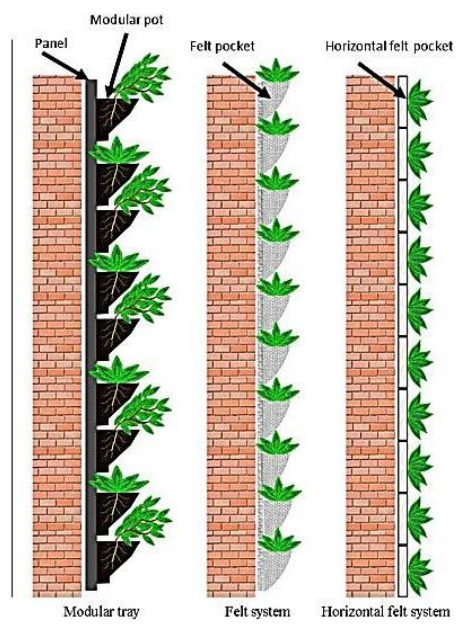

Figure 8, Schematic diagram of Typologies of LWS, (Source: [10])

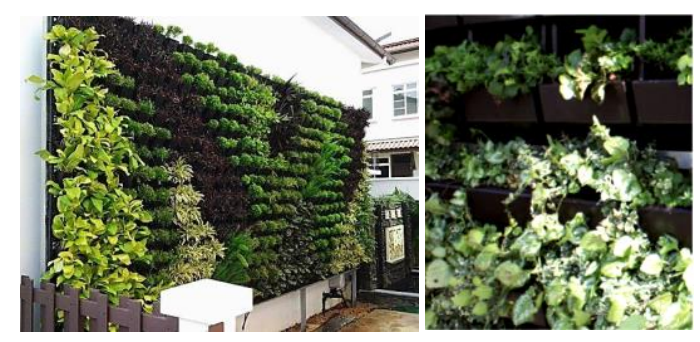

Figure 9, Modular Living walls (planter boxes), (Source: [9])

The heat reduction abilities of various forms of vertical gardens have been analysed, according to a study conducted in Singapore. Plants, growing media, and substrate materials used by each system were researched in this study. The temperature behind the walls decreased in all vertical greeneries studied, but the vegetation coverage and denser plant achieved greater temperature reduction. In comparison with other vertical greenery systems, LWS with modular panels have attained higher temperature reduction levels [5]. The research was focused on ambient temperatures, but there was no recognition of the internal temperature and humidity. 


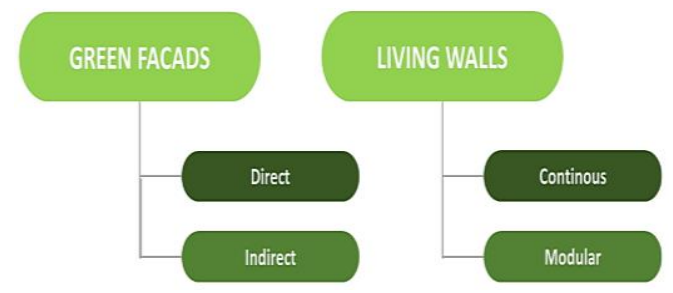

Figure 10, GFS \& LWS subcategories

(Source: Researcher)

\section{B. Benefits of VGS}

Urbanization induced ecological pollution to promote the knowledge that vertical gardens will have a positive effect on the urban life quality. Environmental, economic, and social influences of VGS are mitigation of global warming, conservation of energy, noise insulation, carbon sequestration, production of oxygen, reduction of rainwater effects, wildlife habitat formation, particle filtering, creation of urban agriculture, significant effect on human health, producing pleasant and aesthetic views.

\section{1) Environmental Benefits}

VGS is able to contribute to both the living space and the region by building a living atmosphere within. The form of the plants reduces the intra-urban transmission and heat generated through the building surfaces. Environmental influences of the VGS can generally be reviewed as mitigating the effect of Urban Heat Island (UHI), improving air quality, enhancing energy efficiency, increasing biodiversity, reducing noise, offering habitat for wildlife, and designing areas for urban agricultural methods.

\section{Mitigation of Urban Heat Island (UHI) impact}

Due to the retention of heat in the hermetic surfaces, urban areas are considerably warmer than the surrounding rural areas, and this phenomenon is termed the "Urban Heat Island Effect". This aspect, which harms urban residents' lives, leads to the placement of different importance on VGS [14]. Water losses in plants due to evapotranspiration reduce the temperature in the surrounding atmosphere. The air temperature difference among the cities and the neighbouring rural areas varies from $1^{\circ} \mathrm{C}$ to $7^{\circ} \mathrm{C}$. This is according to green areas being replaced by paved surfaces and other infrastructure. By rising summertime high energy demand, air pollution, air-conditioning costs, greenhouse gas releases, heat-related disease, and mortality, UHI will influence cities [15]. In warm climates, the cost of air-conditioning energy can be maintained by lowering the internal temperature by using green facades to cover buildings, in addition to reducing the ambient temperature of the air and the UHI impact. According to Alexandri, E., and Jones, P. (2008) $8-9{ }^{\circ} \mathrm{C}$ temperature reduction is predicted in the ten meters high and fifteen meters long valley in the Hong Kong urban area by greening the facades and the buildings' roofs [16].

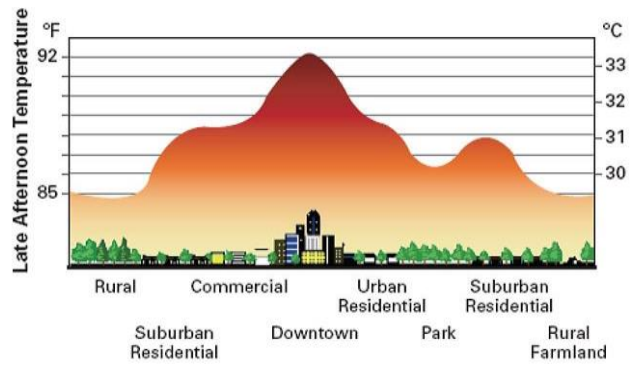

Figure 11, Urban Heat Island (UHI) effect profile, (source: https://deadwildroses.files.wordpress.com/2010/06/heatisland.jpg)

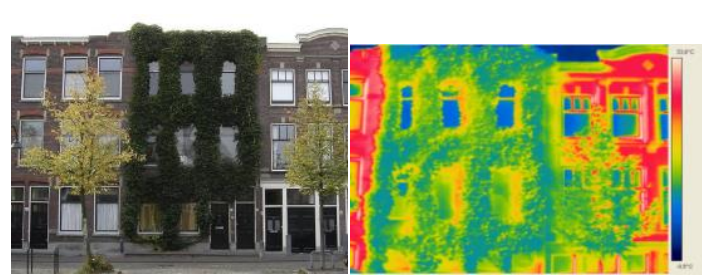

Figure 12, Infrared image showing the effect of vegetation on UHI mitigation (Source: [17]

https://www.researchgate.net/figure/Urban-Heat-IslandEffect-5 fig2 275534248)

As per the comparative study, the outside green wall envelope is up to $10^{\circ} \mathrm{C}$ cooler than that of the bare wall; thus, the LWS U-value is typically lower and significantly reduces cooling loads. The previous study has shown that nonvegetated regions can reach $50^{\circ} \mathrm{C}$ in July, even though vegetated regions continued at $25^{\circ} \mathrm{C}$ [18]. In winter, by moving air among the vegetation and the wall and producing a barrier against the wind that minimize cold air coming in, green wall techniques serve as an isolation layer. The energysaving degree based on many factors, such as structure skin type, climate, and plant coverage density.

\section{Enhancement of Energy Efficiency}

VGS only prevents the heat flow out of the wall and decreases the temperature of the surface. VGS reduces the vertical heat movement, producing an air cavity between the wall and the vegetation, and therefore heat is obtained during cold climate and reduced during hot climate. Vertical gardens play the function of a protecting barrier that creates better solar protection that can minimize the external load efficiency hence the need for cooling. The previous studies have shown that VGS reduces heat gain and that its surface temperature is lower than that of an uncovered wall.

\section{Enhancement of Air Quality}

Indoor air quality has been listed as one of the first five health issues by the environmental protection organization. The significance of interior air quality has been recognized by the discovery that people in classrooms, workplaces, and closed areas are at a risk for having a disease. Vertical greenery systems that rise the number of green areas in cities, with the leaves and roots of plants within their structure, retain exhaust gases and dust throughout the air. By separating carbon dioxide (CO2) formed by living things and water, plants absorb the sunlight and supply oxygen. Vertical garden systems isolate the air chemical particles such as $\mathrm{SO} 2, \mathrm{CO}$, 
$\mathrm{CO}, \mathrm{NO} 2$, and $\mathrm{VOC}$ in indoor and outdoor spaces. In addition, plants raise the oxygen level by transforming carbon dioxide gas into oxygen within the air throughout the day [19].

\section{Sound Insulation}

The purpose of the afforestation along the highways is the sound insulation function of the plants. The usage of plants as a road noise buffer is a guide for vertical gardens in which to minimize noise relative to surface reflectivity. In addition, it is understood that planted rooftops transmit less sound than unplanted ones into the inner space. Green walls, as shown in Figure 14 have high insulation reached 30 decibels than that of bare walls. The sound insulation level created by the vegetated wall actually based on the elements which affect the noise reduction, containing plant species, growing media depth, materials used for the VGS structural elements, and the air cavity between the vegetation and the wall. So, it is a fact that plants play a functional and aesthetic role in the dense urban structure and along the highways in the transmission and absorption of the noise emitted [5], [20], [21].

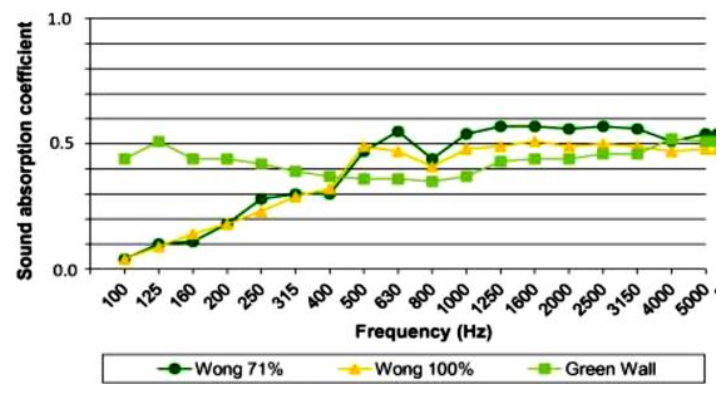

Figure 13, Sound absorption coefficient value measurement results between Regular wall \& a green wall (Source: [21])

\section{Increased Biodiversity}

Vertical gardens must be used to improve biodiversity, and their advantages must be studied. Some urban research focuses on green roofs and creates habitats for plant-animal species. Vertical gardens are a natural enhancement to these spaces, with their potential connection to the roof. Large-scale vertical garden projects have been developed using natural native vegetation to establish habitat for urban reforestation. Storm water ponds and filtration methods are used to help restore the habitat of some plants. In addition, vertical gardens offer shade.

\section{Urban Agriculture}

Increased urbanization and a decrease in rural areas have a negative effect on agricultural areas. Due to the increasing population and urbanization, new food production techniques are being studied. Vertical agricultural systems, which have evolved due to the reduction of horizontal regions, are an example of this. This technique, healthy and fresh food, can be created and can be part of sustainable urban models.

\section{2) Economic Benefits}

Profitability is a major factor in the use of technology. Economic analyses are performed to fund costs and viability of innovations over their lifespan. The installation cost ranges from $\$ 100$ to $\$ 1200$. Economic benefits are correlated with the environmental benefits of the VGS [22]. Green infrastructure could be a cost-effective option for gray infrastructure, the phenomenon of urban heat island (UHI) is popular in concrete structures. Heat is consumed by the building through the day and the building's temperature increases in comparison to its surroundings and produces a heat island. VGS can appear as a cooler due to plant foliage and vegetation evaporative cooling. Evapotranspiration has a cooling impact due to water evaporation in the leaves. VGS will minimize the wind impact by 75 percent and the heating need by 25 percent. To discover the economic benefits of VGS by use of vegetation around buildings that minimize climatic pressure, to preserve the integrity of construction that contributes to the sustainability of buildings and less need to envelop maintenance.

Vegetation can create visual contrasts from the heavily built-up city climate. Attractive areas with green infrastructure often encourage inhabitants to move to these areas and raise the value of the local estate.

\section{Storm Water Management}

Heavy rain and strong winds may affect the VGS. Wastewater decreases as rainwater collected in the hydroponic system are used for plant irrigation.

\section{Bio filtration of Air Quality}

VGS can function in a building as a bio-filter and oxygen produce such as, $27 \mathrm{~g}$ of oxygen could be produced in a $25 \mathrm{~m} 2$ plant density in an hour. This is equivalent to $150 \mathrm{~m} 2$ of leaf surfaces will provide human nutrition for one year. The large quantity of oxygen originates from a small leaf. When the vegetation is big enough its effect is greater. In addition, a VGS of $60 \mathrm{~m} 2$ will filter 40 tons of hazardous gasses and 15 $\mathrm{kg}$ of heavy metal. VGS indoor plants can eliminate benzene, VOCs, and other harmful fumes [23]. Users with respiratory illnesses and asthma may benefit from these aspects.

\section{3) Social Benefits}

Living in urban areas, surrounded by noise, traffic, concrete, and pollution also has a significant negative effect on physical and mental health. Vegetation gives this difficult environment, through all that provides a strong connection to nature that is lacking in the current region.

\section{Health impacts}

As per scientific research, vegetation alone decreases stress and provides beneficial physiological responses. Plants also promote human health and well-being, contributing to improved efficiency and productivity.

\section{Aesthetic Impacts}

Damaged building surfaces, hard structures, and grey facades have a negative impact on the city's aesthetics. With VGS, these undesired impacts can be minimized. Using innovative materials and technologies to encourage sustainable urban development. Distorted building surfaces 
may be covered with vegetation and urban images may be substituted. Based on conducted studies to decide the aesthetic effect of green facades on the building, incorporated green walls with buildings were more favoured and considered to be even more aesthetically pleasing than without vegetation.

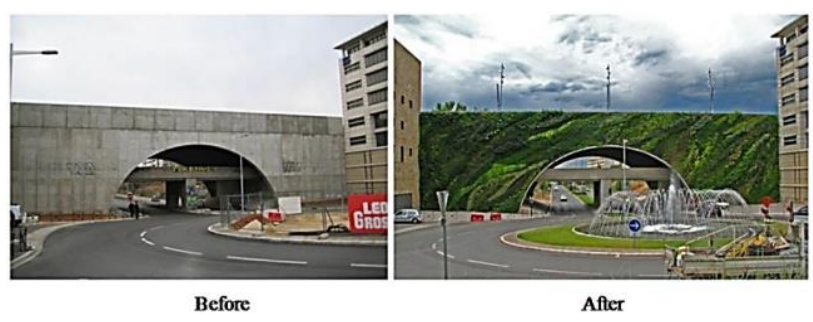

Figure 14, Bridge in France before and after, (Source: https://www.intechopen.com/books/advances-in-landscapearchitecture/vertical-gardens)

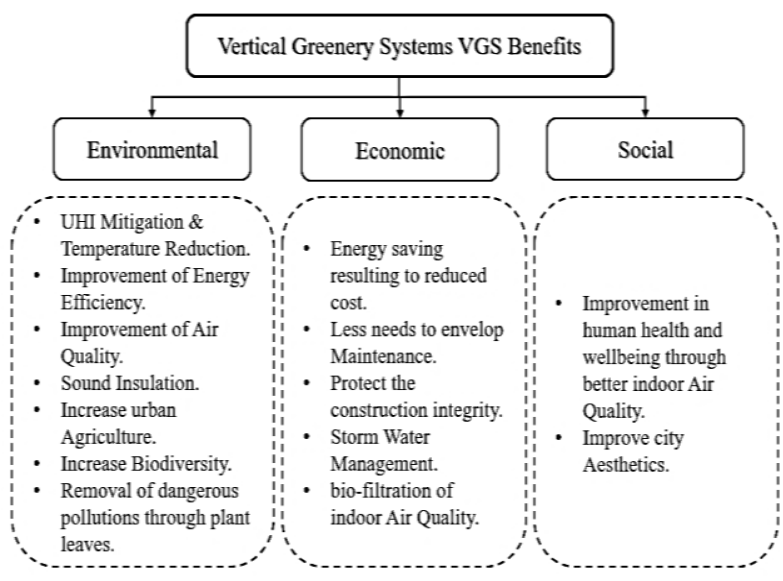

Figure 15, Vertical Greenery Systems benefits (Source: Researcher)

\section{VGS THERMAL PERFORMANCE}

The second section focuses on the thermal impact of VGS on buildings, which is very significant throughout summer periods in hot climates.

Three major features have defined by researchers as essential factors, which determine the effect of VGS as a passive energy-saving system in a building: obstruction of solar radiation by the vegetation, the evapotranspiration from plants and substrate, and at last the thermal insulation provided through vegetation and substrate.

\section{A. Shading Impact}

VGS could save building's envelope from overheating thru shading, the overall solar radiation affecting the green façade relies on the canopy's physical properties, applied in these three ways; absorbed by the canopy, reflected in the atmosphere, or transferred through the leaf. The shading impact of the VGS largely relies on a leaf density represented within Leaf Area Index (LAI), which affects the evapotranspiration from the vegetation and the quantity of shading offered. Overall Thermal Transmission Value (OTTV) is a thermal efficiency measurement of the envelope of the building [24]. As per Wong, N.H. et al. (2009). Study simulated the influence of VGS on the OTTV of a 20 story building with a full glass facade, found that the GFS is capable of minimizing the ambient temperature value and that the 50 $\%$ greenery covering and shading factor of 0.041 will decrease the OTTV of a glass façade building about $40.68 \%$. In addition, they found a relationship between the Leaf Area Index (LAI) and the shading factor. It implies that the high value of Leaf Area Index can be converted into less solar transmittance, which is why thermal efficiency for the building can be reduced [4].

\section{B. Thermal Isolation}

The creation of a microclimate environment in the air gap between the vegetated wall and the building's facade, serving as just a thermal buffer, thus reduces the heat flux within the building envelope through controlling the wind speed and the ambient air temperature [24].

The transfer of heat thru the concrete wall is considerably lower if it is covered by a vegetation layer, as per Perini, K. et al. (2011), examined the disparity between the GFS connected indirectly to the wall (with an air gap) and the GFS connected to the wall. Direct GFS with dimension $4 \mathrm{~cm}$ air gap was proven more effective in minimizing wind speed through building envelope than indirect GFS with dimension $20 \mathrm{~cm}$ air gap according to shorter vegetated surface spans. In addition, a small temperature decrease of $1.2^{\circ} \mathrm{C}$ was observed on awall surface behind the direct GFS compared to a bare wall surface and a decrease of $2.7^{\circ} \mathrm{C}$ was observed for indirect GFS [25].

\section{Evapotranspiration Impact}

There must be energy for the incidence of the evapotranspiration process. This physical component is responsible for the so-called "evaporative cooling." The evaporative cooling of soil and leaves relies on plant species and the sunlight. It has an impact on the climate, because dry conditions or the wind effect improve evapotranspiration [26]. Mostly in tropical climates, the cooling impact of vegetation has been confirmed by the temperature measurement at various heights. The highest temperature change was $4.2^{\circ} \mathrm{C}$. The research found that the cooling impact is restricted by height [27]. As per Wong, N. H.et al. (2010) researched eight different LWS and GFS based on free-standing concrete walls. LWS with modular panels offered a greater opportunity to minimize the wall surface temperature and have the smallest normal range of average temperature change of the wall surface relative to the GFS. The maximum decrease in wall surface temperature related to the cooling impact of the LWS is $11.58^{\circ} \mathrm{C}$ [5].

Evapotranspiration water has been the most efficient and competitive way to cool a building. The cubic meter absorbs $680 \mathrm{kWh}$ of evaporated water. The vegetated façade represents the highest capability for enhancing the environment within and around the building and reducing the building surface 
temperatures. Evapotranspiration is perhaps the most significant environmental advantage of GFS in urban environment. This impacts urban hydrology, decreases surface temperatures and enhances the management of runoff rainwater. In summary, current research on VGS shows that these systems have significant potential to enhance the interior building temperature, increase energy efficiency and decrease the urban heat island (UHI) phenomenon.

\section{1) Orientation Impact on VGS Thermal Performances}

VGS can be applied to any orientation of buildings, but it is important to specify the orientation of the maximum energy efficiency investigation on climate, geographical characteristics, and latitude, and that it is different from one region to another. As per Perez, G. et al, (2011) the orientation impact was examined in such an experiment with in the arid Mediterranean continental climate. And the highest efficiency of GFS application in reducing Temperature on south-east, south-west, and north-west direction. The results indicate that the GFS is capable to lower the temperature about $5.5^{\circ} \mathrm{C}$ and rising about $15.2^{\circ} \mathrm{C}$ in the south-west direction. In addition, the influence of the GFS on the air gap temperature within the vertical vegetation and the wall surface has been examined during the summer and winter periods. within the winter, the air gap temperature was around $3.8^{\circ} \mathrm{C}$ higher than outside, and inversely through summer, the temperature was $1.4^{\circ} \mathrm{C}$ cooler than outside. So, VGS will protect the envelope from cold winter and hot summer, and, in order to identify the most effective orientation for the establishment of the VGS, the optimal energy efficiency should be evaluated individually for each climate and weather condition. [11].

\section{2) Ventilation Impact on VGS Thermal Performances}

Ventilation and air movement are essential for the development of a thermal environment. Openings have an essential role in producing natural ventilation. VGS is used as wind barriers [11], LWS based mainly on substrate materials. This efficiency is sufficient in the cold environment which can reduce the heat decline from within the buildings, but in a hot climate. The influence of VGS and ventilation in reducing temperature was recognized in an analytical study in Thailand [28]. GFS was located next to room's window, the room temperature was examined in the same situation without any greenery, this study has repeated by applying natural ventilation to the system. It analyzed that GFS decreased internal temperature and the best temperature reduction was achieved whenever natural ventilation has been applied to the system. The internal temperature was $9.9^{\circ} \mathrm{C}$ cooler than that of the external temperature.

\section{VGS ADVANTAGES AND DISADVANTAGES}

TABLE 2

ADVANTAGES AND DISADVANTAGES OF VGS CALSSIFICATIONS (SOURCE: [7] )

\begin{tabular}{|c|c|c|c|c|}
\hline$\frac{\mathbb{3}}{5}$ & 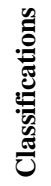 & 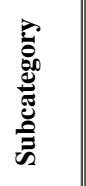 & Advantages & Disadvantages \\
\hline \multirow{3}{*}{ 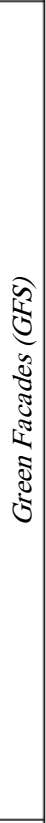 } & 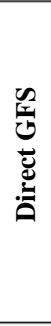 & 岕 & $\begin{array}{l}\text { Low cost } \\
\text { Not any } \\
\text { contributing } \\
\text { materials (growing } \\
\text { media, support, } \\
\text { irrigation) } \\
\text { Low environmental } \\
\text { problems. }\end{array}$ & $\begin{array}{l}\text { Spontaneous } \\
\text { development of } \\
\text { vegetation. } \\
\text { Limited variety of plant } \\
\text { species/ climate } \\
\text { adaptation } \\
\text { Dispersed growth on the } \\
\text { facade. } \\
\text { Slow facade coverage. } \\
\text { Maintenance difficulties. }\end{array}$ \\
\hline & \multirow[t]{2}{*}{ 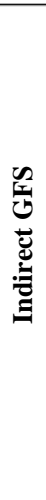 } & 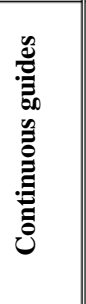 & $\begin{array}{l}\text { Low water } \\
\text { consumption. } \\
\text { enhancement } \\
\text { guidance for } \\
\text { vegetation }\end{array}$ & $\begin{array}{l}\text { Limited variety of plant } \\
\text { species/ climate } \\
\text { adaptation } \\
\text { Slow facade coverage. } \\
\text { Dispersed growth on the } \\
\text { facade. } \\
\text { Some materials have a } \\
\text { high environmental } \\
\text { burden. }\end{array}$ \\
\hline & & 畜 & $\begin{array}{l}\text { Managed Drainage / } \\
\text { irrigation } \\
\text { Light support. } \\
\text { Capacity to build } \\
\text { and dismantle for } \\
\text { repair purposes. }\end{array}$ & $\begin{array}{l}\text { Limited variety of plant } \\
\text { species/ climate } \\
\text { adaptation } \\
\text { High cost. }\end{array}$ \\
\hline \multirow{4}{*}{ 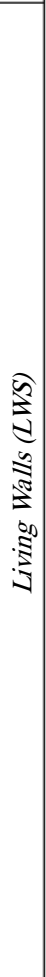 } & 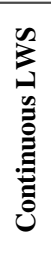 & 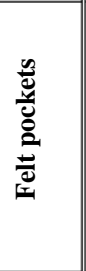 & $\begin{array}{l}\text { Flexible and } \\
\text { lightweight } \\
\text { Regular growth. } \\
\text { An increased plant } \\
\text { selection. } \\
\text { Regular water and } \\
\text { nutrients } \\
\text { distribution. }\end{array}$ & $\begin{array}{l}\text { High water and nutrients } \\
\text { consumption. } \\
\text { Complex in } \\
\text { implementation } \\
\text { Lack of space for root } \\
\text { growth. } \\
\text { Regular maintenance. } \\
\text { High cost. }\end{array}$ \\
\hline & \multirow{3}{*}{ 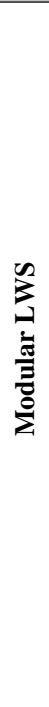 } & 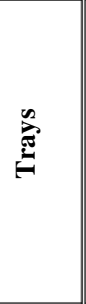 & $\begin{array}{l}\text { Managed Drainage } \\
\text { / irrigation } \\
\text { Capacity to build } \\
\text { and dismantle for } \\
\text { repair purposes. } \\
\text { An increased plant } \\
\text { selection }\end{array}$ & $\begin{array}{l}\text { Complex in } \\
\text { implementation } \\
\text { High cost. } \\
\text { Heavier methods } \\
\text { Surface types restricted } \\
\text { to trays' measurements. } \\
\text { Large environmental } \\
\text { load of some used } \\
\text { materials. }\end{array}$ \\
\hline & & 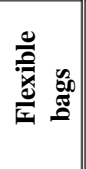 & $\begin{array}{l}\text { Adaptable to } \\
\text { sloped surfaces } \\
\text { An increased } \\
\text { plant selection } \\
\text { aesthetic value }\end{array}$ & $\begin{array}{l}\text { Complex in } \\
\text { implementation. } \\
\text { Heavier methods due to } \\
\text { growing media } \\
\text { High cost. }\end{array}$ \\
\hline & & 莺 & $\begin{array}{l}\text { An increased } \\
\text { plant selection } \\
\text { aesthetic value } \\
\text { attractive designs }\end{array}$ & $\begin{array}{l}\text { Complex in } \\
\text { implementation } \\
\text { Lack of space for root } \\
\text { growth. } \\
\text { Surface types restricted } \\
\text { to trays measurements. } \\
\text { High cost. }\end{array}$ \\
\hline
\end{tabular}




\section{MENA REGIONAL CLIMATE}

The Middle East and North Africa region (MENA) is a climate change hot spot where summer warms much faster than in the rest of the world. Some parts of the region are already among the hottest locations globally. cities feel an increasing Urban heat island (UHI) effect and most capital cities in the middle east face four months of exceedingly hot days every year. The importance of VGS lies in mitigating outdoor heat gain, reducing UHI, and improving thermal building performance in this regional climate especially in a hot-arid climate that characterizes the MENA region.

The success of the VGS retrofitting projects largely depends on selecting the correct system. the climate conditions impact the operation of vertical greenery systems because the climate significantly influences the thermal efficiency of buildings and the particular features of plant species that should be used and the rate of growth.

\section{CASE STUDIES}

Different case studies of VGS implementations are studied in the last part of the research study, the case studies were chosen in KSA \& UAE because that they face similar climatic circumstances to Egypt. New projects are being analyzed to understand VGS impacts on buildings in a hot climate, as an approach for saving energy, reducing the temperature, and analyzing the thermal effect.

\section{A. Liwa International School (LIS), AlAin, UAE.}

Liwa International School was chosen for the study to examine the thermal efficiency of the VGS. The school is situated in a hot climate of Al-Ain city, United Arab of Emirates which is the first "Green School" in the UAE, at latitude $24^{\circ} 16$ 'and longitude $55^{\circ} 36^{\prime} \mathrm{E}$ in the southwest of the city [29]. LIS has chosen a sustainable green building initiative in the World Future Energy Summit 2010 (WFES). The goal of the project was to transform the school from a conventional building to a sustainable green building through minimizing energy used and raising its efficiency. Three sustainable strategies were chosen: a) the application of green wall systems to minimize heat gain; b) the recycling system for Greywater; and c) photovoltaic panels mounted on the building's roof to generate energy for lighting and also irrigation systems [30].

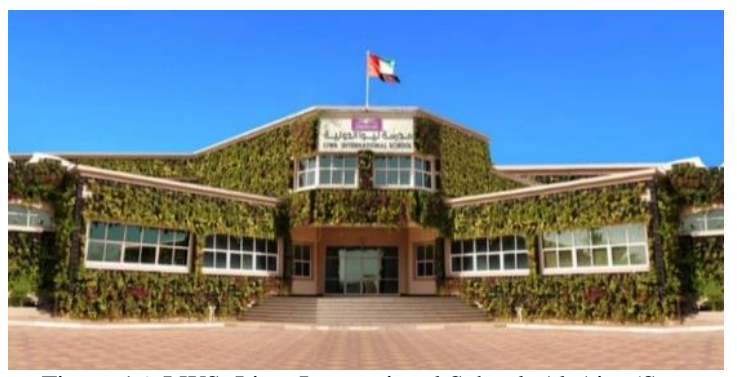

Figure 16, LWS, Liwa International School, Al-Ain, (Source: https://whichschooladvisor.com/uae/school-review/liwainternational-school

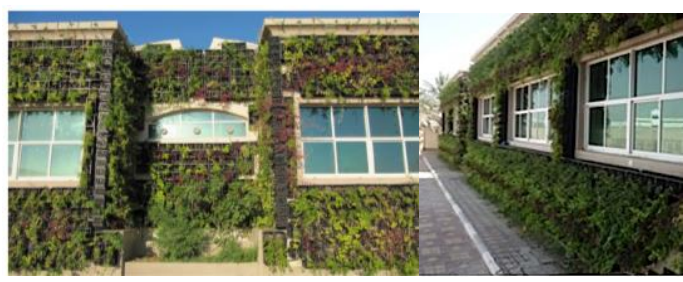

Figure 17, The irrigation system delivers Greywater to vegetation that drapes Liwa's external facades.

(source: https://www.greenprophet.com/2011/04/al-ainjungle-school/

https://www.thenationalnews.com/uae/green-school-happyto-be-a-blackboard-jungle-1.434660)

The city of Al-Ain is described by high humidity, high temperature, and sunshine. Daytime temperatures in summer range between $35^{\circ} \mathrm{C}$ to $50^{\circ} \mathrm{C}$, but daytime temperatures in winter range between $25^{\circ} \mathrm{C}$ to $35^{\circ} \mathrm{C}$. Usually, the appropriate humidity ranges between 13 percent (very dry) to 88 percent (very humid) throughout the year [31]. A vegetated LW was installed on the facades using LW planter units, which made of plastic boxes, set on building's façades with irrigation channels, and a different variety of plant species.
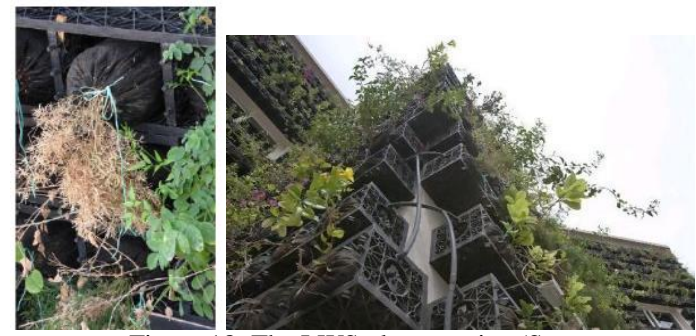

Figure 18, The LWS planter units, (Source:

https://www.pinterest.com/pin/142285669447960988/ https://www.thenationalnews.com/uae/green-school-happy-tobe-a-blackboard-jungle-1.434660)

\section{Thermal performance of the LWS on LIS}

According to Haggag, M. \& Hassan, A. (2015) Two related classrooms were tested in an experimental study on LIS: the first classroom with bare walls and the another with green LWS. Both classrooms have been facing the east and are built of hollow concrete blocks with a heat absorption value of 0.6 covered by white Stucco plaster. Both for bare and green LWS, temperatures at 4 locations were observed to recognize the thermal efficiency impact of the LWS on outdoor and indoor spaces. These positions shall include ambient temperature; interior air temperature; internal surface temperature; and external surface temperature. The experiments were done from 1 July to 1 August to confirm the maximum ambient temperature and intensity of solar radiation. The cooling load for both the LWS and bare walls were measured and analyzed from the measured temperature data to decide the impact of the LWS on the cooling load reduction of the chosen spaces [29].

The result from the experiment confirms that the outside bare wall surface temperature remained about $54^{\circ} \mathrm{C}$ whereas 
the LWS temperature remained at $48^{\circ} \mathrm{C}$. The decreased external temperature on the LWS creates a lower internal temperature comparative to the bare wall. The inner temperature of a bare wall stands at $52^{\circ} \mathrm{C}$, whereas the inner LWS surface temperature remains at $46^{\circ} \mathrm{C}$.

The conclusion of this study also confirms that the internal LWS surface stays cooler than the internal bare wall surface throughout the peak daytime (about $4^{\circ} \mathrm{C}$ to $6^{\circ} \mathrm{C}$ ) and peak nighttime (about $1^{\circ} \mathrm{C}$ to $2.5^{\circ} \mathrm{C}$ ). This shows that by observing the room from overheating, the LWS saves more energy throughout the daytime than the nighttime [32].

This study assumes that the VGS's shading influence will decrease the peak interior air temperature by $5^{\circ} \mathrm{C}$ to $7^{\circ} \mathrm{C}$ thru July and minimize the peak air conditioning energy consumption by $20 \%$. As a result, the decrease in the VGS's internal temperature and ambient air temperature is mostly because of the reduced heat gain created by the LWS, the evaporative cooling created by the irrigation water, and the thermal insulation provided by the low thermal conductivity of the soil and plant foliage.

\section{B. King Abdallah Financial District (KAFD) Conference Center, Riyadh, KSA}

The following case study focuses on the application of vertical vegetation developed by the SOM architectural group in Riyadh, KSA. The Conference Center is designed as an architectural extension of "The Wadi" angular desert landscape, and the building and the adjacent area are joined by its organic profile and facet skin. The structural and the architectural group led their scientific team to design and implement the integration of landscape and structure, where its sharp edge structure is characterized by the sand-setting tents scene as an extension of Saudi Arabia's desert landscape and culture. Three different structural systems are made up of the KAFD Conference Center. Parking and mechanical installations are located in the fourth story underground substructure. Over the ground, the conference facilities are contained in two free steel structures. Large, column-free spaces are spanned by a combination of steel trusses and composite columns through a lateral system of reinforced concrete walls. A "Mega-roof" free structural steel crosses these buildings and holds directly onto the concrete substructure. Riyadh city is described by high temperatures and arid climates. Daytime summer temperatures vary from $34.7^{\circ} \mathrm{C}$ to $44^{\circ} \mathrm{C}$, but daytime winter temperatures vary from $14.3^{\circ} \mathrm{C}$ to $22^{\circ} \mathrm{C}$ [33].

KAFD conference center designed to attain LEED Platinum certification, this building employs several innovative sustainability strategies, where was chosen three systems: a) Interior Green living wall system; b) Green Roof system, proposing at reducing heat gain; and c) a Greywater recycling system.
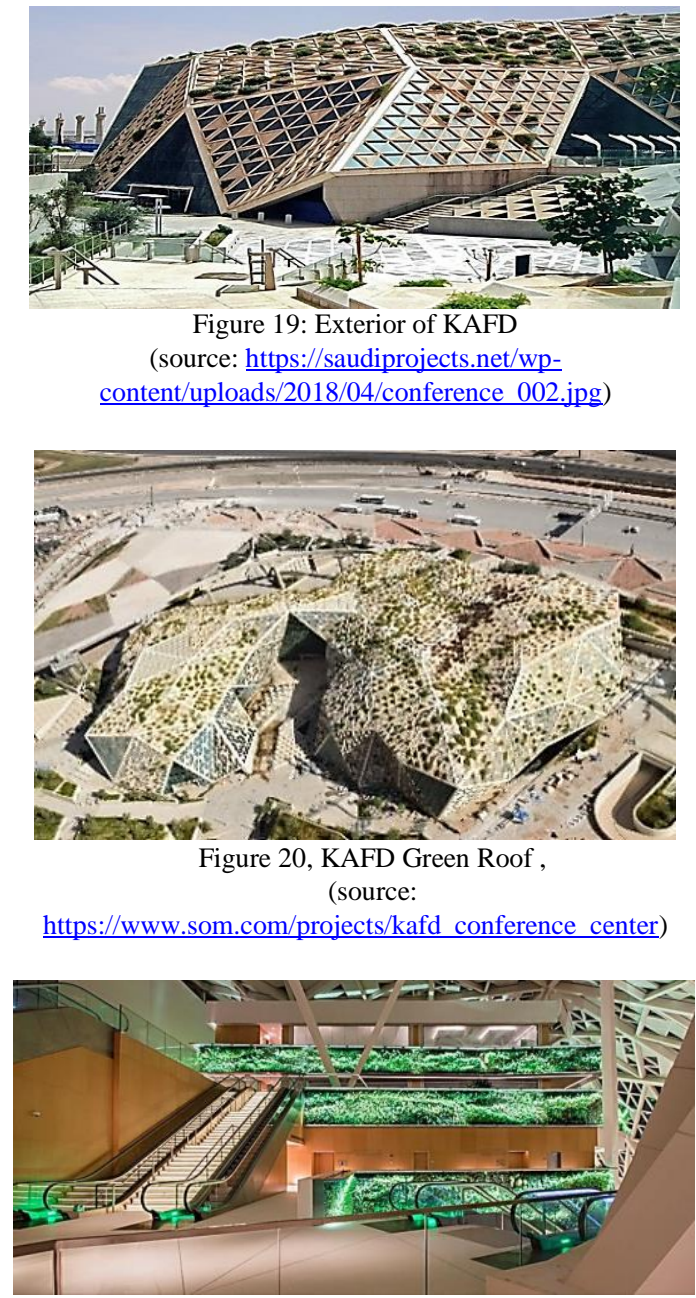

Figure 21, KAFD Interior Green LWS,

(Source: https://saudico.com.sa/projects/conference.html https://www.skyscrapercenter.com/building/kafdconference-centre/17176)

\section{Thermal performance of Green LWS and Green roofs}

Shading targets in the façade reduce solar heat gain, from the important features of the center in the exterior Green roof which covered by many shrubs containing indigenous dissert grasses to minimize the irrigation requirements such as; Aloe Vera, furthermore, application of interior green living walls which cultivated by a mixture of denser vegetation can increase the evaporative cooling benefits inside the building, enhancing the thermal insulation, absorbing dust, working as natural air filtration, thereby, improving interior air quality.

These strategies will decrease the internal air temperature of the building by $5^{\circ} \mathrm{C}$ through the summer period and minimize the air-conditioning demand by up to 20 percent.

Depending on the prevailing conditions vertical gardens are capable of thriving without water, The LWS and green roof irrigation system depended on Greywater. Water conservation is essential to supply irrigation to abundant landscape areas. Greywater runoff collected from adjacent parcels stored in underground cisterns and used to irrigate outdoor and indoor vegetation. 


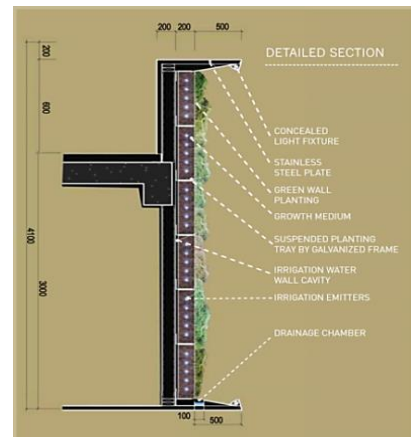

Figure 22, Detailed Interior LWS in KAFD. (Source: https://archello.com/story/8902/attachments/photos-videos/3)

Inside the center, Continuous Green ribbons of plants and gardens link the interior levels with the building's cladding design. Interior living walls create overlapping planted. The internal typology is intended to simulate the oasis, consisting of plant species from the desert region, such as xeric ferns, wild agaves, and perennials. The surface plantings that can endure the harsh climatic conditions of the KSA are accentuated by palm groves, cycads, and shrubs, resulting in a major reduction in internal temperature. The result is a suspended, self-contained eco-system that releases oxygen, cools the air in summer, insulates the building against the cold in winter, and makes nature a step closer to people in cities. It produces habitats for wildlife, promotes the microclimate, filters out noise and dust in the building's immediate surroundings, and enhances biodiversity overall.

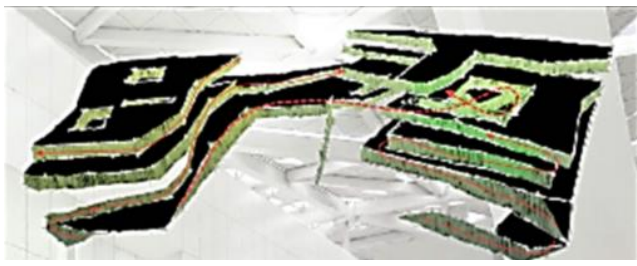

Figure 23, Interior Green Ribbon Concept (Source:

https://archello.com/story/8902/attachments/photos-videos/2)
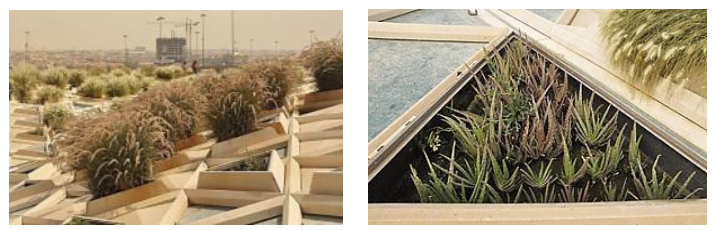

Figure 24, plant species selection in green roofs to suit the climate zone such as: Aloe Vera \& Doranta Repens (Source: photo by researcher)

In summary, the current study shows that the creative techniques used in the KAFD conference center: building shape, green living walls, vegetation, and irrigation systems have all been combined to minimize internal air temperatures, increase energy efficiency, and enhance evaporative cooling caused by plant irrigation and thermal insulation.

\section{CHALLENGES AND LIMITATIONS OF VGS USAGE IN EGYPT AND MENA REGION}

Vertical greenery systems are a creative approach to a sustainable future with many potentials. VGS has various advantages such as reducing emission levels, decreasing overall temperature, and improving biodiversity. Despite these advantages, some risks may be discussed under the principal headings in Egypt and the MENA region as follows: maintenance and difficulties, irrigation systems, high cost.

\section{A. Maintenance and Difficulties}

It is important to manage vertical gardens because they are living systems. Maintenance based on VGSs' categories, plant types, and climatic conditions. insulation materials and Carrier panels used for VGS are typically resistant to ecological conditions. Maintenance is also connected to vegetation diversity and irrigation systems. But it should be replaced if there is a defective carrier panel or isolation material. As in all landscaping projects, vegetation adapted to ecological conditions should be used. And there's still a damaged plant which must be replaced. In addition, routine maintenance needed for irrigation systems shouldn't be affected by the cold throughout the winter months. It should also be noted that the desired effect is given by the addition of plant food materials and regular pruning work. In conclusion, the maintenance to be conducted on vertical surfaces is more complex than on the horizontal surface.

\section{B. Irrigation Systems Difficulties}

A drip irrigation system with an automatic timing mechanism is used often on VGS, and many irrigation system failures can cause problems with time and cost. With the limitations of the irrigation system, routine maintenance should also be carried out and adequate steps to be taken against the cold can be taken in winter in the irrigation systems. Dry land, leaky water, and large containers are other problems. Usually, if sufficient and regular irrigation is not provided, the soil used will dry up. The containers used in VGS, especially when exposed to full sun, tend to dry the soil and plants quickly. The water also begins to flow out of the set-up. The wall and the entire process would be affected by all the leaked water from VGS.

It should also be noted that due to evaporation, the VGS used in the south façade requires more water than in the north façade [19]. It is important to control the number of nutrients during the irrigation system's routine maintenance.

\section{High Cost}

The main factor of the VGS implementation is the cost, the expensive work components that will be used on a vertical surface are more costly than those on a horizontal surface. As follows, expensive components in the VGS: carrier profile, components of the irrigation system, insulation material, drainage system, plant species, plant growth media, and 
regular maintenance costs (irrigation system maintenance, plant species, and drainage system) [25], standard VGS can cost between $\$ 60$ to $\$ 160$ per square foot with a highly laborintensive. The VGS requires high-level maintenance, which makes it complex to implement. Proper tools and machinery, including cranes, are required for its perpetuation.

\section{CONCLUSION}

The expanding urban population is increasing the rate of buildings. With increasing structures, natural spaces in urban are disappearing so that various ecological issues occur. As a result of numerous studies looking for a solution to this problem, the idea of "vertical greenery systems" was created. Nature is built into the vertical plane in these structures, and the urban areas, which are getting darker day by day, would provide the greenery they lack.

\section{The research has extracted the following results:}

- The primary objective throughout the design of the VGS is to resolve the issue of declining urban vegetation and provides a balanced ecosystem.

- VGS environmentally contributes to improving the urban life quality through increasing biodiversity, sound insulation, providing habitats for plant-animal species, reducing the UHI effect, helping to minimize outdoor heat gain, thereby reducing energy usage, creating opportunities for urban agriculture, and making buildings biologically vibrant through the integration of nature into buildings.

- VGS economically increases energy efficiency, preserves the integrity of the architecture that contributes to the longevity of buildings, and decreases the need for maintenance. Besides, water efficiency may also be given if rainwater is used for irrigation. The economic contribution is the key to a sustainable city model.

- VGS socially has a positive influence on human health and well-being. This leads to an improvement in productivity and innovation.

- VGS does not only have advantages, but also some risks. Given the benefits of vertical gardens, it must be said that vertical gardens are important for urban areas and leading to energy efficiency in general. In sustainable development, VGS is also a central factor. It is assumed that all of these risks would be decreased when there is enough time for regular maintenance work and sufficient financial support.

- The implementation of the two VGS systems classifies the difference between green facades (GFS) and living walls (LWS) according to the building's orientation, position, space, and height, and the choice of VGS is decided according to the wind direction and the sun orientation.

- There is an immediate relationship between the thickness of the VGS plants foliage and the decrease in surface temperature, so that the thicker the foliage, the higher the reduction.

- According to the study, living wall systems using modular panels have attained better levels of reducing temperature compared to other vertical green systems.

- Climate conditions affect the operation of vertical greenery systems because the climate significantly influences the thermal efficiency of buildings and the particular features of plant species that should be used and the rate of growth.

- In general, the implementation of VGS, well enough designed, can be a valuable solution for enhancing the thermal efficiency of buildings with a consequent saving of energy. This can occur in a variability of ways, including shading, thermal insulation, and evaporative cooling.

- The air gap between the bare wall façade and the vegetated wall has a significant effect on the thermal efficiency of the façade by providing a microclimate that separates the façade from the external environment.

- According to case studies in the research, there is a variation between the air temperature at the front of a bare wall and a vegetated wall, creating VGS will minimize the internal air temperature about $4^{\circ} \mathrm{C}$ to $5^{\circ} \mathrm{C}$ for buildings throughout the summertime.

\section{RECOMMENDATION}

1. It is proposed that vertical greenery systems (VGS) be used to improve environmental conditions in urban areas, as they may enhance the overall energy performance of buildings and reduce the UHI effect.

2. In view of Egypt's limited economic difficulties, it is suggested that sponsoring facilities to be given by business developers to sponsor vertical gardens implementation.

3. It is suggested to use advanced hydroponic techniques in vertical greenery systems, they don't need to be connected to the soil in the ground, they are completely waterproof, with automatic irrigation system, using special materials and plants, and from the most essential advantages of it is the low maintenance of VGS and the water-efficient using state of the water recycling techniques, The light porous material takes the place of the soil and thus the walls are indeed very light, weighing less than $35 \mathrm{~kg} / \mathrm{m} 2$.

4. It is recommended to use a Greywater recycling system in the VGS irrigation system, which nowadays is recognized as a substantial alternative source of water.

5. There are various suggestions that are recommended to be applied in the design of VGS to enhance the thermal situation.

$\checkmark$ The plant species and vegetation must be carefully selected on the envelope of building in the urban environment. The plant selection should take into consideration adaptability to the surrounding climate. 
$\checkmark$ The vegetation carried out on the urban façade must be placed appropriately in order to obtain maximum sunlight.

$\checkmark$ Maintenance should be regularly to be sure of the efficiency of the system and protecting building from any leakage of water, Maintenance planning should also include risk management.

\section{AUTHORS CONTRIBUTION}

1- Conception or design of the work 50/50

2- Data collection and tools 50/50

3- Data analysis and interpretation 60/40

4- Funding acquisition 40/60

5- Investigation 40/60

6- Methodology 50/50

7- Project administration 60/40

8- Resources 50/50

9- Software $60 / 40$

10-Supervision $40 / 60$

11-Drafting the article 50/50

12-Critical revision of the article. 50/50

13-Final approval of the version to be published 50/50

The corresponding author is responsible for ensuring that the descriptions are accurate and agreed upon by all authors.

\section{REFERENCES}

[1] Safikhani, T., Abdullah, A.M., Ossen, D.R.\&Baharvand, M. (2014). A review of energy characteristic of vertical greenery systems, Renewable and Sustainable Energy Review, 40, 450-462.

[2] Newton, J., Gedge, D., Early, P., Wilson, S. (2007). Building Greener: Guidance on the use of Green roofs, Green walls and Complementary Features on Buildings. London, UK: CIRIA publication.

[3] Abdullah, A.M., Safikhani, T., Ossen, D.R. \&Baharvand, M. (2014). Thermal Impacts of Vertical Greenery Systems. Environmental and Climate Technologies, 14(1) 5-11.

[4] Wong, N.H., Tan, A.Y., Tan, P.Y. \& Wong, N.C. (2009). Energy simulation of vertical greenery systems, Energy Buildings. 41(12) 14011408 .

[5] Wong, N., Tan, A., Chen, Y., Sekar, K., Tan, P.\& Chan, D. (2010). Thermal Evaluation of Vertical Greenery Systems for Building Walls. Building and Environment, 45(3) 663-72.

[6] Francis, R.\& Lorimer, J. (2011). Urban reconciliation ecology: The potential of living roofs and walls. Journal of Environmental Management,92(6) 1429-37.

[7] Manso, M.\& Castro, J. (2015). Green Wall Systems: A Review of their Characteristics. Renewable and Sustainable Energy Reviews, 41, 863871

[8] Perini, K., Ottelé, M., Haas, E.M. \&Raiteri, R. (2013). Vertical Greening Systems, a Process Tree for Green Façades and Living walls, Urban Ecosystems. 16, 265-277.

[9] Besir, A.B \&Cuce, E. (2018). Green roofs and facades: A Comprehensive review. Renewable and sustainable Energy reviews. 82(1) 915-939.

[10] Bustami, R. A.,Belusko, M., Ward, J.\& Beecham, S. (2018). Vertical Greenery systems: A Systematic Review of research trends. Building and Environment, 146, 226-237.

[11] Perez, G., Rincon, L., Vila, A., Gonzalez. JM \&Cubeza, LF (2011).Behavior of green facades in Mediterranean Continental climate. Energy Conversion and Management.52(4) 1861-1867.

[12] Palermo, S. A. \& Turco, M. (2020). Green Wall systems: where do we stand? Earth and Environmental Science. 410, 012013.

[13] Baran, Y. \&Gültekin, A.B. (2017). Green Wall Systems: A Literature Review. Proceedings of 3rd International Sustainable Buildings Symposium, pp 82-96.
[14] Yeh, Y. (2009). Green Wall-The Creative Solution in Response to the Urban Heat Island Effect. National Chung-Hsing University.

[15] Eumorfopoulou, E. \&Kontoleon, K. (2009). Experimental approach to the contribution of plant-covered walls to the thermal behavior of building envelopes. Building and Environment, 44(5) 1024-1038.

[16] Alexandri, E. \&Jones, P. (2008). Temperature decreases in an urban canyon due to green walls and green roofs in diverse climates. Building and Environment, 43(4) 480-493.

[17] Rakhshandehroo, M., yusof, M.J. \& Najd, M.D. (2015). Green façade (vertical greening): benefits and treads, applied mechanics and materials, $747,12-15$

[18] Pérez, G., Julia, C., Salvador, S. \&Luisa, F. (2017). Green facade for energy savings in buildings: The influence of leaf area index and facade orientation on the shadow effect, Applied Energy. 187, 424-437.

[19] Mir, M.A. (2011). Green façade and Building Structures. MSc, Faculty of Civil Engineering Delft University of Technology.

[20] Green Roofs for Healthy Cities (GRHC). Retrieved from https://greenroofs.org/index.php/about-green-roofs/green-roof-benefits.

[21] Tan, A.Y., Wong, N.H., Tan, P.Y. \& Wong, N.C. (2010). Acoustics evaluation of vertical greenery systems for building walls. Building and environment. 45(2) 411-420.

[22] Curtis, L. \&Stuart, M. (2010). Enhancing CHBE Indoor Air Quality: Biowall Technology, UBC Social Ecological Economic Development Studies (SEEDS) Student Report, University of British Columbia.

[23] Darlington, A.,Dat, J.\& Dixon, M. (2001). The bio filtration of indoor air: air flux and temperature influences the removal of toluene, ethylbenzene, and xylene. Environmental Science \& Technology, 35, 240- 246

[24] Raji. B., Tenpierik, M. \&Dobbelsteen, A.V. (2015). The impact of greening systems on building energy performance: A Literarure review. Renewable and sustainable energy reviews. 45, 610-623.

[25] Perini, K., Ottele, M., Fraaij. A., Hass. E., Raiteri, R. (2011). Vertical greening systems and the effect on air flow and temperature on the building envelope. Building and environment. 46(11) 2287-2294.

[26] Perez, G., Rincon, L., Vila, A., Gonzalez, J.M, \&Cabeza, L.F. (2009). Energy Efficiency of Green Roofs and Green Facades in Mediterranean Continental climate. 11 th international conference thermal energy storage, pp 1-8.

[27] Wong, N.H., Chen, Y. Ong, C.L. \&Sia, A. (2003). Investigation of Thermal Benefits of Rooftop garden in the Tropical environment, Building and Environment. 38(2) 261-270.

[28] Sunakorn, P. \&Yimprayoon, C. (2011). Thermal performance of Bio facade with Natural Ventilation in the Tropical Climate, Procedia Engineering, 21, 34-41.

[29] Haggag, M. \& Hassan, A. (2015). Cost-benefit analysis of living wall systems on school building skins in a hot climate. Energy and sustainability V: Special contribution. 206, pp 3-11.

[30] Haggag, M., Elmasry, S.K., \& Hassan, A. (2012). Design with nature: integrating green façade, into sustainable buildings with reference to Abu Dhabi, design and nature. 160, 37-47.

[31] Climate: Al Ain, UAE https://en.climate-data.org/asia/united-arabemirates/abu-dhabi/al-ain-1210/

[32] Haggag, M., Hassan, A, Elmasry, S.K. (2014). Experimental study on reduced heat gain load climate, energy and buildings. 82, 668-674.

[33] Climate: Riyadh, KSA https://en.climate-data.org/asia/saudiarabia/riyadh-region-2029/

\section{Title Arabic:}

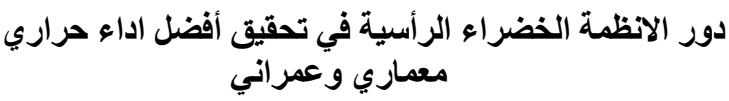

Arabic Abstract:

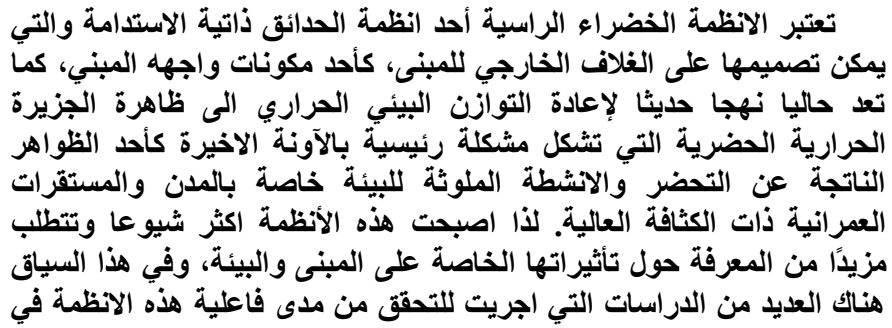


تحسين البيئة الحضرية وتعزيز كفاءة المباني، وبشكل خاص مجال دراسة

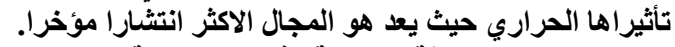

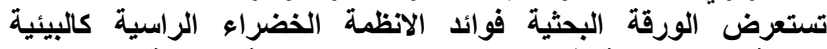

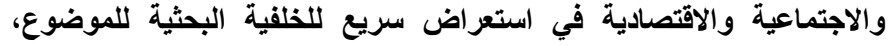

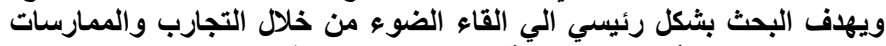

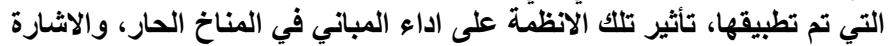

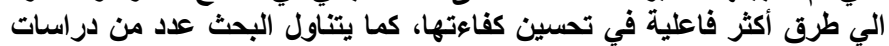

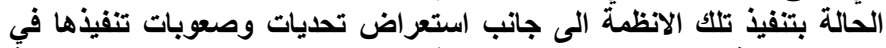

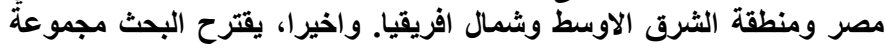
من التوصيات لاستخد/مها كتكنولوجيا واعدة لنهج الاوسئ حضري مستخام. 